\title{
Short-term outcomes associated with bilateral internal thoracic artery grafting
}

\author{
Sayedur R. Khan, Abul Kashem, Mirza A.K. Mohiuddin, Jahangir Kabir
}

\begin{abstract}
Background: Bilateral internal thoracic artery (BITA) grafting is associated with improved long-term survival and graft patency compared to single internal thoracic artery (SITA) graft and saphenous vein graft in coronary artery bypass grafting (CABG). However, BITA grafting may adversely affect early in hospital mortality and morbidity due to deep sternal wound infection. Hence, we carried out this study to evaluate early outcomes of BITA grafting in different configuration in our hospital and to assess safety and applicability of BITA grafting as a routine procedure.

Methods: A retrospective cross sectional study was conducted in September 2014 where all 134 patients using bilateral ITA for coronary artery bypass (CABG) at United Hospital, Dhaka, Bangladesh from January 2009 to September 2014 were included. BITA grafting were used in either in-situ or Y-graft technique. We reviewed and evaluated patients' characteristics and short-term
\end{abstract}

outcomes. The short-term outcomes included in hospital mortality and major morbidities.

Results: Out of 134 patients, 129 (96\%) patients were male. The mean age was $48.73 \pm 8.42$ yrs ranging from 28 to 72 yrs. Hypertension and smoking were the most common cardiac risk factors. There was no mortality in both BITA in-situ and BITA Y-graft groups. Most common postoperative complications were fever $(26 \%)$, and arrhythmia (7.5\%). Only one female patient $(0.7)$ had sternal wound complication. Elderly, obesity and COPD were not observed to be associated with sternal wound complication.

Conclusion: Short-term outcomes of BITA grafting for CABG is excellent with no significant difference between BITA in-situ and BITA Y-graft groups.

Keywords: BITA, CABG, short-term outcomes, Y-graft.

(Bangladesh Heart Journal 2016; 31(1) : 3-9)

Introduction:

Despite advances in Percutaneous Coronary intervention $(\mathrm{PCl})$, coronary artery bypass surgery (CABG) remains the best therapy for severe multivessel ischemic disease and the most commonly performed cardiac operations worldwide. ${ }^{1}$ The gold standard for CABG is the left internal thoracic artery (LITA) to the Left Anterior Descending Artery (LAD) due to the inherent characteristics of internal mammary artery endothelium and improved run-off of the LAD territory. ${ }^{2}$.

Ten years after CABG upto $95 \%$ of internal thoracic artery (ITA) grafts remain in pristine condition whereas around three quarters of vein grafts are blocked or severely diseased. ${ }^{3}$ Specially, patients who received two ITA grafts

Department of Cardiac Surgery, United Hospital Limited Dhaka-1212. had approximately $10 \%$ risk for reintervention at 10 years, those with one ITA had $20 \%$ risk and with no ITA had $30 \%$ risk for reintervention at 10 years. ${ }^{4}$ Bilateral internal thoracic artery (BITA) grafting is associated with improved survival, better event-free life and reduced reintervention relative to CABG with single ITA grafts and saphenous vein grafts. ${ }^{5}$ Manipulation of the diseased aorta in elderly patients is one of the major risk factors for stroke after CABG. Composite arterial grafts including BITA graft with a non-touch aortic off pump coronary artery bypass (OPCAB) technique offers major advantages in such a population who are at highest risk of stroke. ${ }^{3}$

Although BITA grafting appears to offer superior revascularization, it is associated with increased surgical time, increased technical challenges, increase the risk of early mortality and major morbidity, in particular 
increased rates of sternal wound complication. ${ }^{1,4}$ In addition, patients receiving BITA grafting had higher rates of bleeding requiring postoperative mediastinal reexploration $(2.9 \%$ vs $0.6 \%)$ along with increased rates of wound complication ${ }^{6}$

Advantages of skeletonized ITA are increase conduit length, provides superior flow and greater graft diameter, reduces the incidence of deep sternal wound infection, less postoperative paresthesia and pain, improved graft patency. ${ }^{7}$ Therefore, skeletonization of the ITA leaves enough of the sternal circulation intact to facilitate proper wound healing. ${ }^{8}$

A crucial point in bilateral ITA grafting is the proper use of the right ITA. When the right ITA is used in-situ, the right coronary system is the easiest to reach and next to proximal LCX branches. But the right ITA is best used as a graft to the LAD or the marginal branches (over or under the aorta). ${ }^{9}$ In-situ RITA crossing midline anterior to aorta is at risk of ITA injury in redo operation. In-situ ITA graft is a better conduit as it carries its homeostatic melieu with it and so is less prone to thrombus formation. ${ }^{10,11}$ BITAY configuration allows the larger number of arterial anastomoses and total revascularization of the whole myocardium in selected patients. However, Composite T or Y grafting with BITA brought back concern of a potential "steal phenomenon "of the LITA by the RITA. ${ }^{10}$

Considering the above, we carried out this study to review our experience of performing BITA grafting using both ITA in-situ graft and BITAY-graft technique for CABG. We also evaluated and compared short-term outcomes of BITA grafting in both configuration and assessed safety and applicability of BITA grafting as a routine procedure.

\section{Patients and Methods:}

A retrospective cross sectional study was conducted in which all patients undergoing bilateral internal thoracic artery grafting for coronary bypass surgery only at United Hospital, Dhaka, Bangladesh from January 2009 to September 2014 were included. During this period, 134 patients underwent BITAgrafting. Out of 134 patients, 111 patients received BITA Y-graft and 23 patients BITA in-situ for CABG.

\section{Surgical technique}

During the study period both left and right internal thoracic artery were harvested by skeletonization technique. One ITA was used to bypass left anterior descending artery (LAD) and second ITA was used to bypass either LCX or RCA system using in-situ or Y-graft technique according to surgeon preference based on position of targeted vessels ( Figure-1 and Figure-2). All grafting were done on off pump beating heart (OPCAB).

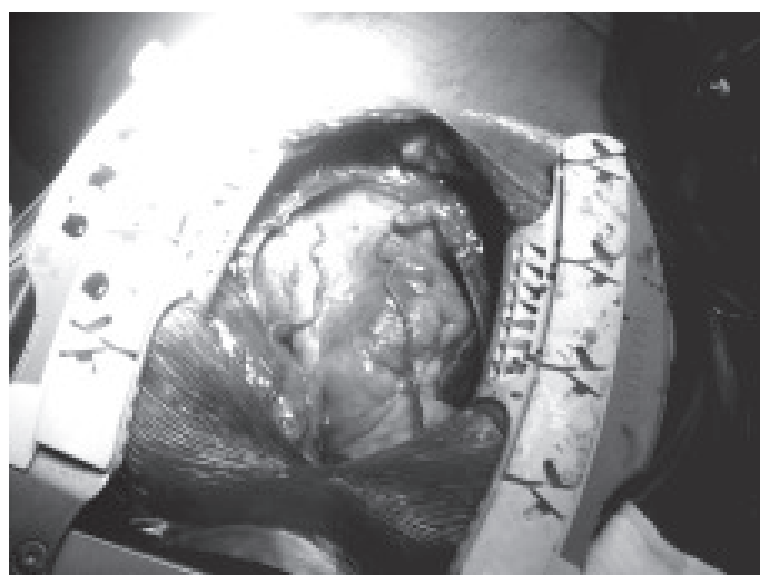

Fig.-1: LITA and RITA in-situ

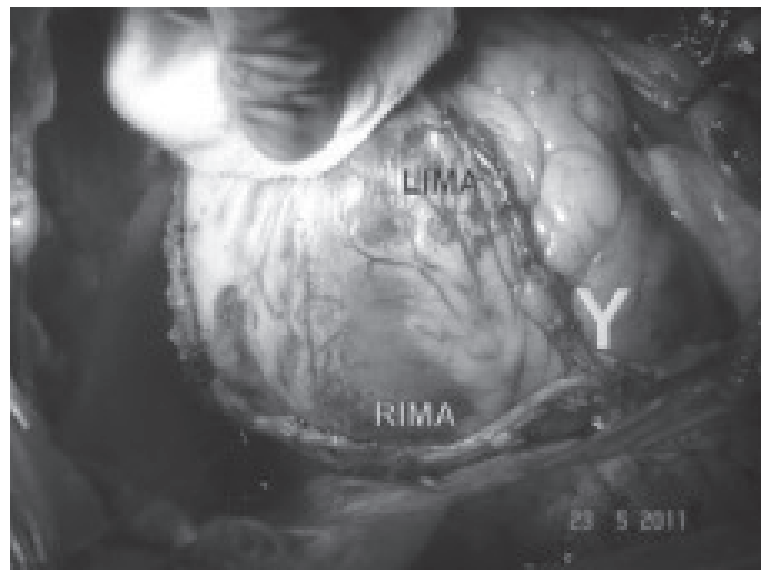

Fig.-2: LITA/LIMA and RITA/RIMA Y graft.

\section{Data collection}

The data were obtained by retrospective review of the patients' hospital records. The demographics, clinical profile, co-morbid factors, underlying disease pathology and severity, type of conduits used and corresponding target vessels, operation time, intensive care unit (ICU) and total hospital stay were recorded. We compared the short term outcomes as defined by the Society of Thoracic Surgeons (STS) including 30-day operative death, permanent stroke, renal dysfunction or renal failure requiring dialysis, any reoperation, prolonged ventilation (>48 hours), deep sternal wound infection, perioperative myocardial infarction, arrhythmia and fever for assessing the safety and efficacy of the procedure in both groups (insitu and $\mathrm{Y}$ graft group) of patients undergoing BITA grafting for $\mathrm{CABG}$.

\section{Statistical analysis}

The data collected were entered in Epi-Info and analyzed through SPSS (version 16.00). Results are expressed as Frequencies and means, as appropriate, for the demographic data and clinical characteristics of the study 
population. Statistical analysis comparing two groups with the unpaired 2-tailed $t$ test for the means or $\div 2$ test for categorical variables. The frequencies with which each conduit was used for grafting were also calculated and tabulated. Significance was set at $p<0.05$. The chisquare test was used to associate different postoperative complications with the pre-operative patient characteristics and to determine if any association observed was a statistically significant one.

\section{Results:}

134 patients were selected for the study, out of them 111 $(82.84 \%)$ patients had BITA Y-grafting and rest 23 $(17.16 \%)$ patients had BITA in-situ grafting. Male were $129(96.27 \%)$ and $5(3.73 \%)$ female patients. Patients had a wide range of age from 28 to 72 years with the mean age being $48.73 \pm 8.42$ years. There were $13(9.7 \%)$ patients being more than $60 \mathrm{yrs}$ of age. $55(41.02 \%)$ patients were overweight $\left(\mathrm{BMI}=25-30 \mathrm{~kg} / \mathrm{m}^{2}\right)$, and three $(2.27 \%)$ patients were obese $\left(\mathrm{BMI}>30 \mathrm{~kg} / \mathrm{m}^{2}\right)$. Among the cardiac risk factors, Hypertension $(70.1 \%)$ and Smoking (56\%) were most common followed by Diabetes $(41.81 \%) .8(6.0 \%)$ chronic kidney disease, $5(3.7 \%)$ calcified aorta and $5(3.7 \%)$ chronic obstructive pulmonary disease (COPD) present in these patients. Majority $(64.3 \%)$ of patients had triple vessel disease (TVD) and $17.8 \%$ patients had TVD-LM. 5 (3.9\%) patients had low LVEF(less than $40 \%$.) (Table-1).

Right internal thoracic artery (RITA) was harvested and used as an in-situ graft in 23 patients and remaining 111 patients received RITA as Y-graft with LITA. The target vessels for the in-situ LITA were mainly Left anterior descending artery (LAD), then Ramus intermedius (RI) and Obtuse marginal (OM) arteries while those for the in-situ RITA artery included Right coronary artery (RCA) as well as LAD. Average no. of $3.48 \pm 1.12$ and $3.72 \pm .93$ distal anastomoses per patient done in in-situ and $Y$ graft group respectively and no. of arterial graft per patient was 2.22 \pm .518 and $2.33 \pm .61$ in in-situ and Y-graft group respectively. Average operative time was $5.03 \pm 1.05$ hours and $4.87 \pm 1.14$ hours in BITAY graft and BITA in-situ group respectively. Mean ICU stay was $3.04 \pm 1.38$ days with range of 1 to 12 days and $3.48 \pm 1.50$ days with range of 2 to 8 days in BITAY graft and BITA in-situ group respectively. Average total hospital stay was relatively more in BITA insitu group than BITA Y graft. (Table-2)

Hospital mortality and perioperative morbidity were reviewed. There was no in hospital mortality in both groups. However, 4 (3.6\%) patients developed perioperative $\mathrm{Ml}$ with raised cardiac enzymes, as type 5 MI define raised cardiac biomarker $>10 \times 99$ th percentile upper reference level (URL) during the first $48 \mathrm{~h}$ following CABG, $5(4.5 \%)$ patients required re-opening for excessive postoperative bleeding and 1 (0.9\%) patient developed respiratory complication (ARDS) that needed prolonged ventilatory support. In BITA Y-graft group, 1 $(0.9 \%)$ female patient developed sternal wound complication with unstable sternum after discharge. She needed re-admission for sternal wound management. She had history of recent $\mathrm{MI}$, diabetes and prolonged preoperative hospital stay (7 days) but hold normal body weight (BMI $24 \mathrm{~kg} / \mathrm{m}^{2}$ ). 1 (4.3\%) patient required IABP support peroperatively and postoperatively needed prolonged artificial ventilation and developed acute kidney injury $(\mathrm{AKI})$ that improved with conservative treatment in BITA in-situ group. Other postoperative complications including arrhythmia (7.5\%) and fever $(26 \%)$ observed in both groups that increased ICU stay and total hospital stay (Table-3).

Table-I

Preoperative characteristics of patients underwent CABG with BITA grafting.

\begin{tabular}{lcccc}
\hline Finding & All patients $(\mathrm{n}=134)$ & BITAYgraft( $\mathrm{n}=111)$ & BITA in-situ graft( $\mathrm{n}=23)$ & $\mathrm{p}$-value \\
\hline Male & $129(96.27)$ & $106(95.5)$ & $23(100)$ & .300 \\
Female & $5(3.73)$ & $5(4.5)$ & $0(0)$ & .182 \\
Mean age in yrs & $48.73 \pm 8.42$ & $48.29 \pm 8.57$ & $50.87 \pm 7.44$ & $2(8.7)$ \\
$>$ >60 yrs n (\%) & $13(9.7)$ & $11(9.9)$ & $1(4.36)$ & .285 \\
BMl>30 n (\%) & $3(2.27)$ & $2(1.9)$ & $14(60.9)$ & .326 \\
Hypertension n (\%) & $94(70.1)$ & $80(72.1)$ & $15(65.2)$ & .093 \\
Smoking n (\%) & $75(56)$ & $60(54.1)$ & $6(26.1)$ & .544 \\
Diabetes n (\%) & $56(41.8)$ & $50(45.0)$ & $2(8.7)$ & .864 \\
CKD n (\%) & $8(6.0)$ & $6(5.4)$ & $1(4.3)$ & $2(8.7)$ \\
COPD/asthma (\%) & $5(3.7)$ & $4(3.6)$ & $3(15.8)$ & $16(69.6)$ \\
Calcified Aorta n(\%) & $5(3.7)$ & $3(2.7)$ & & \\
EF <40\% & $5(3.9)$ & $2(1.8)$ & & \\
TVD & $87(64.9)$ & $71(64)$ & &
\end{tabular}

Paresenthesis (\%), Mean \pm standard deviation

CKD-Chronic Kidney Disease, COPD-Chronic Obstructive Pulmonary Disease, EF-Ejection Fraction, TVD-Triple vessel disease, 
Table-II

Distribution of patients by peroperative and postoperative findings in both groups

\begin{tabular}{lcccc}
\hline Findings & All patients $(\mathrm{n}=134)$ & BITA Y-graft $(\mathrm{n}=111)$ & BITA in-situ graft $(\mathrm{n}=23)$ & $\mathrm{p}$-value \\
\hline Total Graft no. & $3.68 \pm .97$ & $3.72 \pm .93$ & $3.48 \pm 1.12$ & .277 \\
No. of arterial graft & $2.31 \pm 0.59$ & $2.33 \pm 0.61$ & $2.22 \pm 0.518$ & .396 \\
No of venous graft & $1.37 \pm 0.954$ & $1.39 \pm 0.946$ & $1.26 \pm 1.01$ & .752 \\
Operative time & $5 \pm 1.06$ hours & $5.03 \pm 1.05$ hours & $4.87 \pm 1.14$ hours & .522 \\
ICU stay & $3.11 \pm 1.41$ days & $3.04 \pm 1.38$ days & $3.48 \pm 1.50$ days & .26 \\
\hline Total Hospital stay & $9.9 \pm 1.78$ days & $9.86 \pm 2.71$ days & $10.09 \pm 1.99$ days & .43 \\
\hline
\end{tabular}

Mean \pm standard deviation

ICU-Intensive Care Unit

Table-III

Distribution of patients by major morbidity

\begin{tabular}{lcccc}
\hline Morbidity & All patients $(\mathrm{n}=134)$ & BITAY-graft $(\mathrm{n}=111)$ & BITA in-situ graft $(\mathrm{n}=23)$ & $\mathrm{p}$-value \\
\hline Perioperative MI & $4(3.0)$ & $4(3.6)$ & $0(0.0)$ & .355 \\
Re-opening for Bleeding & $5(4.0)$ & $5(4.5)$ & $0(0.0)$ & .300 \\
Prolong ventilation & $2(1.5)$ & $1(0.9)$ & $1(4.3)$ & .215 \\
Respiratory complication & $1(0.7)$ & $1(0.9)$ & $0(0.0)$ & .648 \\
Renal failure & $1(0.7)$ & $0(0.0)$ & $1(4.3)$ & .027 \\
Stroke & $0(0.0)$ & $0(0.0)$ & $0(0.0)$ & .532 \\
Arrhythmia & $10(7.5)$ & $9(8.1)$ & $1(4.3)$ & .997 \\
Fever & $35(26.1)$ & $29(26.1)$ & $6(26.08)$ & .677 \\
SWI & $1(0.7)$ & $1(0.9)$ & $0(0.0)$ & .648 \\
Re-admission & $1(0.7)$ & $1(0.9)$ & $0(0.0)$ & \\
\hline
\end{tabular}

Paresenthesis (\%)

MI- Myocardial Infarction, SWI-Sternal wound infection

The chi-square test was used to associate different postoperative complications with the pre-operative patient characteristics. Both female sex $(p<0.014)$ and age greater than 60 years $(p<0.025)$ were associated with sternal wound infection (SWI), but diabetes $(p=0.236)$, obesity $(p=0.949)$, COPD $(p=0.843)$, smoking $(p=0.258)$, and CKD $(p=0.800)$ were not associated with SWI.

\section{Discussion}

The use of the internal thoracic artery (ITA) as a conduit for $C A B G$ has changed greatly since its initial introduction in the 1950s and 1960s. Bilateral internal thoracic grafting (BITA) has been demonstrated to be associated with improved long-term survival and graft patency when compared with both single ITA grafting and with the use of venous grafts alone. ${ }^{12}$ A mean $15 \%$ increase in the 20 year survival has been observed in such patients. ${ }^{13}$ On the molecular level, it has been observed that there is an enhanced release of endothelial derived relaxing factor nitric oxide (NO) from the ITA as compared to venous grafts. ${ }^{14} \mathrm{NO}$ directly regulates blood flow and inhibits platelet function and indirectly allows lesser neutrophil adhesion to the endothelium that coincides with increased short and long-term vessel patency. ${ }^{15-17}$ However, some cardiothoracic surgeons have reservations about the routine use of BITA due to procedure requiring better surgical skills, takes longer time to perform, and may adversely affect early in-hospital mortality and morbidity, in particular due to deep sternal wound infections. ${ }^{6}$ Most however have reported no increased risk in perioperative death or morbidity conferred. ${ }^{18}$ Hence, we carried out this study to evaluate the early outcomes observed in our hospital to assess the safety and applicability of BITA grafting as a routine procedure in a tertiary care Hospital in Bangladesh.

In our study most of patients was male (96.27\%) and mean age was $48.73 \pm 8.42$ years range from 28 to 72 
years. BITA grafting has traditionally been performed in younger patients having a greater life expectancy. The trend of relatively younger patients (mean age 48 years), and male $(96 \%)$ having undergone BITA grafting at our hospital matches with other studies ${ }^{19}$. Thirteen $(9.7 \%)$ patients were more than $60 \mathrm{yrs}$ of age in this study. Elderly patients can be benefited from arterial grafts. ${ }^{20,21}$ Elderly patients have sub-optimal venous conduit due to varicosities and calcification, 22 prone to early occlusion. In our study, elderly patients had showed early return to normal life without complication. In our study population, most of patients $(80 \%)$ had good Left ventricular ejection fraction (LVEF) and 5 (3.7\%) patients had LVEF less than $40 \%$. Most of study showed that an important criterion related to the use of arterial conduits is the functional status of the left ventricle. Patients received BITA also had a slightly better mean EF (0.55 vs. 0.52) than those who only received a LITA. ${ }^{2}$ Significantly impaired left ventricular function is associated with limited life expectancy, on the other hand increase in the 20-year survival period is observed in patients with BITA grafting. ${ }^{23}$

In the study patients, $56(41.81 \%)$ patients had diabetes and $53(39.6 \%)$ patients were dyslipidaemic. Literature suggests diabetes as a risk factor for postoperative mediastinal wound infection and hence a possible relative contraindication for doing bilateral ITA grafting in these patients. ${ }^{24}$ However, in diabetic patients, increased use of skeletonized harvesting techniques when performing a BITA grafting along with other infection prevention strategies have shown a reduction in deep sternal wound infection (DSWI) comparable to that seen in LITA patients. ${ }^{2}$ In our study, higher incidence of DSWI was found in diabetic patients (1 of $56 ; 1.8 \%$ ) than in nondiabetic patients ( 0 of $78 ; 0 \%$ ) but this difference was not significant $(p=0.236)$. In this study $75(56 \%)$ patients were smoker, $55(41 \%)$ patients overweight and 3 patients obese (BMI > 30) and five (3.7\%) patients had COPD. Obesity is considered an independent risk factor for mediastinitis. ${ }^{25}$. In our study, none of obese and COPD patients developed wound infection postoperatively.

BITA grafting is associated with increased early morbidity and mortality, ${ }^{26,27}$ specifically the occurrence of deep sternal wound infection (DSWI) and the well-documented increased risk of death that accompanies it. DSWI has been reported to occur in as low as $0.3 \%$ and as high as $14 \%$ of BITA procedures and is thought to be a result of the decreased sternal perfusion exacerbated by bilateral versus unilateral harvest of the ITA. ${ }^{2}$ Skeletonization of the ITA leaves enough of the sternal circulation intact to facilitate proper wound healing. In our study all ITA were harveseted by skeletonization technique, therefore sternal wound complication was minimum $(0.7 \%)$.

The assessment of the safety of the procedure has usually been compared in literature with the results of using unilateral ITA for grafting. In our study there was no mortality But $4(3.6 \%)$ patients developed perioperative $\mathrm{MI}, 5(4.5 \%)$ patients required re-opening, $1(0.9 \%)$ patient needed prolonged ventilatory support, and $1(0.9 \%)$ female patient developed sternal wound complication in BITA Y-graft group. 1(4.3\%) patient developed acute renal failure and required prolonged ventilation in BITA in-situ group. These morbidities in this study were less than other study. ${ }^{28}$ In our study all ITA were harvested by Skeletonization technique, therefore sternal wound complication was minimum $(0.7 \%)$. However, there is lack of association observed among diabetes, COPD, obesity and the development of wound complications.

In the study 134 patients were selected, out of them 111 $(82.84 \%)$ patients had BITA Y-grafting and rest 23 $(17.16 \%)$ patients had BITA in-situ grafting. In bilateral ITA grafting, the right ITA has been flexibly used as an insitu or free graft in combination with an in situ left ITA. An in-situ right ITA can be used by anastomosing it with the left anterior descending coronary artery (LAD) and its diagonal branch along the front of the ascending aorta or to the obtuse marginal artery through the transverse sinus. ${ }^{9}$ A free right ITA, on the other hand can be used as a composite graft allowing for multiple sequential anastomoses. Advocates for both the methods are found in literature. ${ }^{29,30}$ However, identical patency rates have been observed in early, 1-year and the 5-year. Traditionally, inferior rates of RITA patency versus LITA patency have been documented regardless of choice of graft site ${ }^{31}$ and demonstrated no difference in patients receiving an in situ RITA to the left or right coronary system. ${ }^{32} \mathrm{~A}$ prospective study revealed that excellent patency rates were achieved using both BITA configuration with no significant difference in terms of MACCE or ITA patency. ${ }^{10}$ In our study, most of the RITA grafts(82.8\%) were used as a composite $Y$ graft with in-situ LITA and only a few insitu RITA grafts (17.16\%) employed. However, there is no definitive criterion for the selection of patients suitable to undergo BITA grafting. But there was no significant different in short-term outcomes in both configurations. Therefore, excellent short-term outcomes and safety of BITA grafting found in this study and BITA bypass grafting may become a first-line option for patients receiving revascularization. Though our sample size is inadequate to comment on the outcomes, grossly both the groups 
showed comparable rates of perioperative outcomes and early efficacy, with no $p$-value being statistically significant.

\section{Conclusion:}

The short-term outcomes and the safety profile of bilateral ITA grafting in both in-situ and $Y$ graft technique for CABG seems clinically acceptable even for diabetic or obese individuals. A long-term follow-up should be done to assess the cardiac event-free survival of these individuals evaluating the long-term implication of the procedure and hence its applicability as a routine for coronary artery bypass grafting.

\section{References:}

1. Taggart DP, Altman DG, Gray AM, Lees B, Nugara F, Yu LM, et al. Randomized trial to compare bilateral vs. single internal mammary coronary artery bypass grafting: 1-year results of the Arterial Revascularisation Trial (ART).Eur Heart J 2010 ; 31:2470-81.

2. Weiss AJ, Zhao S, Tian DH, Taggart DP, Yan TD. A meta-analysis comparing bilateral internal mammary artery with left internal mammary artery for coronary artery bypass grafting. Ann Cardiothorac Surg 2013;2.

3. Taggart DP. Bilateral internal mammary artery grafting: are BIMA better? Heart 2002; 88:7-9.

4. Hemo E, Mohr R, Uretzky G, Katz G, Popovits N, Pevni D, et al. Long-term outcomes of patients with diabetes receiving bilateral internal thoracic artery grafts. J Thorac Cardiovasc Surg 2012; 1-7.

5. Atkins BZ, OwenVK, Wolfe GW. Conduit selection for improved outcomes in coronary bypass surgery. In: Narin C, editor. Special Tropics in Cardiac Surgery. UK: ISBN, 2012: 143-153.

6. Gansera B, Schmidtler F, Gillrath G, Angelis I, Wenke $\mathrm{K}$, Weingartner $\mathrm{J}$, et al. Does bilateral ITA grafting increase perioperative complications? Outcome of 4462 patients with bilateral versus 4204 patients with single ITA bypass. Eur J Cardiothorac Surg 2006; 30:318-23.

7. Parissis $\mathrm{H}$, Chughta $\mathrm{Z}$, Soo A. Two questions on bilateral internal mammary artery usage. Asian Cardiovasc Thorac Ann 2013; 3.

8. Wehman B, Taylor B. Coronary revascularization using bilateral internal thoracic arteries: safe with skeletonization? J Clin Exp Cardiolog 2013; S7:007.

9. Calafiore AM, Contini M, Vitolla G, Mauro MD, Mazzei $\mathrm{V}$, Teodori G,et al. Bilateral internal thoracic artery grafting: long-term clinical and angiographic results of in situ versus $Y$ grafts. J Thorac Cardiovasc Surg 2000; 120:990-6.

10. Glineur D, Hanet C, Poncelet A, D'hoore W, Funken $\mathrm{JC}$, Rubay J,et al. Comparison of bilateral internal thoracic artery revascularization using in situ or $Y$ graft configurations. Circulation 2008; 118:S216S221.

11. Hanif HM, Saeed ZI, Sheikh A, Sharif H. Short term complications after bilateral internal mammary artery grafting-a retrospective study. J Pak Med Assoc 2012; 62; 745-49.

12. SabikIII JF, Lytle BW, Blackstone EH, Houghtaling $\mathrm{PL}$, Cosgrove DM. Comparison of Saphenous vein and internal thoracic artery graft patency by coronary system. Ann Thorac Surg 2005; 79:544-51.

13. Lytle BW, Blackstone EH, Loop FD, Houghtaling $\mathrm{PL}$, Amold JH, Akhrass R, et al. Two internal thoracic artery grafts are better than one. J Thorac Cardiovasc Surg 1999; 117: 855-72.

14. Lüscher TF, Diederich D, Siebenmann R, Lehmann K, Stulz P, Segesser LV,et al. Difference between Endothelium-Dependent Relaxation in Arterial and in Venous Coronary Bypass Grafts. N Engl J Med 1988; 319: 462-7.

15. Yang Z, Oemar BS, Carrel T, Kipfer B, Julmy F, Luscher TF. Different proliferative properties of smooth muscle cells of human arterial and venous bypass vessels: role of PDGF receptors, mitogenactivated protein kinase, and cyclin-dependent kinase inhibitors. Circulation 1998; 97: 181-7.

16. Chello M, Mastroroberto P, Perticone F, Celi V, Colonna A. Nitric oxide modulation of neutriphilendothelium interaction: difference between arterial and venous coronary coronary bypass grafts. $\mathrm{J}$ Am Coll Cardiol 1998; 31: 823-6.

17. Dorman MJ, Kurlansky PA, Traad EA, Galbut DL, Zucker M, Ebra G. Bilateral intertnal mammary artery grafting enhances survival in diabetic patients: A 30-year follow-up of propensity score-Matched Cohorts. Circulation 2012; 126: 2935-42.

18. Asraf SS, Shaukat N, Akhtar K, Love H, Shaw J, Rowlands DJ, et al. A comparison of early mortality and morbidity after single and bilateral internal mammary artery grafting with the free right internal mammary artery. Br Heart J 1994; 72:321-6. 
19. Mohammadi S, Dagenais F, Doyle D, Mathieu P, Baillot R, Charbonneau E, et al. Age cut-off for the loss of benefit from bilateral internal thoracic artery grafting. Eur J Cardiothorac Surg 2008; 33: 977-82.

20. Nasso G, Coppola R, Bonifazi R, Piancone F, Bossetti G, Speziale G. Arterial revascularization in primary coronary artery bypass grafting: Dirrect comparison of 4 strategies-results of the Stand-inY Mammary Study. J Thorac Cardiovasc Surg 2009; 137: 1093-100.

21. Jones JW, Schmidt SE, Miller CC $3^{\text {rd }}$, Beall AC Jr, Baldwin JC. Bilateral internal thoracic artery operations in the elderly. J Cardiovasc Surg (Torino) 2000; 41:165-70.

22. Evans CJ, Fowkes FG, Ruckley CV, Lee AJ. Prevalence of varicose veins and chronic venous insufficiency in men and women in the general population: Edinburgh Vein Study. J Epidemiol Community Health 1999; 53: 149-53.

23. van Domburg RT, Kappetein AP, Bogers AJ. The clinical outcome after coronary bypass surgery : a 30-year follow-up study. Eur Heart J 2009; 30: 453-8.

24. Grossi EA, Esposito R, Harris LJ, Crooke GA, Galloway AC, Colvin SB, et al. Sternal wound infections and use of internal mammary artery grafts. J Thorac Cardiovasc Surg 1991; 102: 342-6; discussion 6-7.

25. Yap $\mathrm{CH}$, Mohajeri M, Yii M. Obesity and early complications after cardiac surgery. Med J Aust 2007; 49: 195-201.
26. Catarino PA, Black E, Taggart DP. Why do UK cardiac surgeons not perform their first choice operation for coronary artery bypass graft? Heart 2002; 88 : 643-4.

27. Mastrobuoni S, Gawad N, Price J, Chan V, Ruel M, Mesana TG. Use of bilateral internal thoracic artery during coronary artery bypass graft surgery in Canada: The bilateral internal thoracic artery survey. J Thorac Cardiovasc Surg 2012; 144: 874-9.

28. Shroyer AW, Coombs LP, Peterson ED, Eiken MC, DeLong ER, Chen A, et al. The society of thoracic surgeons: 30-day operative mortality and morbidity risk models. Ann Thorac Surg 2003; 75: 1856-65.

29. Paz Y, Lev-Ran O, Locker C, Shapira I. Right coronary artery revascularization in patients undergoing bilateral internal thoracic artery grafting: comparison of the free internal thoracic artery with saphenous vein grafts. Interact Cardiovasc Thorac Surg 2002; 1:93-8.

30. Buxton BF, Hayward PA, Newcomb AE, Moten S, Seevanayagam S, Gordon I. Choice of conduits for coronary artery bypass grafting: craft or science? Eur J Cardiothorac Surg 2009; 35: 658-70.

31. Galbut DL, Traad EA, Dorman MJ, DeWitt PL, Larsen PB, Kurlansky PA, et al. Seventeen-year experience with bilateral internal mammary artery grafts. Ann Thorac Surg 1990; 186: 195-201.

32. Kurlansky PA, Traad EA, Dorman MJ, Galbut DL, Zucker M, Ebra G. Location of second internal mammary artery graft does not influence outcome of coronary artery bypass grafting. Ann Thorac Surg 2011; 91: 1378-83; discussion 1383-4. 